\title{
Borders as Privileged Areas for Promotion and Protection of Human Rights to the Migrant Workers
}

\author{
Martinus Sardi \\ Universitas Muhammadiyah Yogyakarta, Daerah Istimewa Yogyakarta, Indonesia
}

\begin{abstract}
Every year, more than five million people cross international borders to go and live in a developed country. They would like better life, although they must face so much risk of their life. Today, more than 214 million people are living outside their countries of origin. Migrants may be subjected to conflict, muliple discriminaion, violence, and exploitation. They have human rights problems that are not yet protected well. The human rights of migrants must be promoted and protected by law. The authorities in the borders must not obstacle the fulfilment and realizations of human rights for all the people, who pass away through them. It is obbligation for the government to garantee the freedom and fundamental rights of people; those are private, civil, politic, economic, social, and culture rights. The UN stablishes the fundamental rights of migrants workers, without any discriminations. The human dignity of the every person is more important than the other things. The value of human person is on their dignity. The rights of the migrants must be respected, protected, and promoted whereever they live. Every independent country has sovranity and self jurisdiction to govern itself. And every country has borders. The border areas are not only as independent of territories, but as privileged areas for protecting and promoting humanity, peace, justice, and human rights. Boders have important significant as a face of the country, for promoting and protecting human rights. The world distribution of opportunities is extremely unequal. The movement of the people as migrants is an expression of looking for better life and needing the protection from the authorities, specially in the borders. The function of borders is not only as line between two countries, but as areas for promoting the humanity in all aspects. The authorities of the borders should respect the humanity capable to promote the peace, manage the conflict, and protect the human rights amongts the migrants. The urgent action today for the government is to create the culture of peace, so the global peace will be realized in all over the world.
\end{abstract}

Keywords: border, migrant workers, human rights and global peace

"In the early beginnings of the 21st century — a century already violently disabused of any hopes that progress towards global peace and prosperity is inevitable — this new reality can no longer be ignored. It must be confronted” (Annan, 2001, p. 9).

\section{Introduction}

Every independent country has sovranity and certain borders. The border areas are not only as independent

Martinus Sardi, MA, Dr., Faculty of Law, Universitas Muhammadiyah Yogyakarta, Daerah Istimewa Yogyakarta, Indonesia. 
territories, but in reality must be capable to be privileged areas for protecting and promoting human rights. In the borders, there are so many social fact and activity of the gouverment, which can realize the fulfilment of human rights for all the people, speacially for the migrant workers and their families. The garantee for the freedom and fundamental rights of people in the border areas, which are private, civil, politic, economic, social, and culture rights, to the challenges of the gouverments. In this moments, the United Nations has decreed the fundamental rights of migrants workers, without any discriminations, although the world distribution of opportunities is extremely unequal and has many discriminitaions. The function of borders is not only as line between two countries, but as areas for promoting the human rights.

\section{The Urgent Action for Protecting and Promoting Human Rights}

It is very interesting for the author what affirmed Mr. Koffi Annan, a former UN Secretary-General, in his acceptance speech upon receiving the 2001 Nobel Peace Prize,

Today's real borders are not between nations, but between powerful and powerless, free and fettered, privileged and humiliated. Today, no walls can separate humanitarian or human rights crises in one part of the world from national security crises in the other.

The author thinks it it is very relevant with our subject to discuss on humanity today.

On the Human Development Report 2009, which remains relevant until now, with entitle: Overcoming Barriers: Human Mobility and Development; it wrote:

Every year, more than 5 million people cross international borders to go and live in a developed country. The number of people who move to a developing nation or within their country is much greater, although precise estimates are hard to come by. Even larger numbers of people in both destination and source places are afected by the movement of others through lows of money, knowledge and ideas. (2009, p. 9)

They would like better life, although they must face so much risk of their life.

In the International Migration: Health and Human Rights, it said:

Today, more than 214 million people are living outside their countries of origin. They have let their homes for a variety of reasons, including conlict, natural disasters or environmental degradation, political persecution, poverty, discrimination and lack of access to basic services and the search for new opportunities, paricularly in terms of work or education. (Chan, Pillay, \& Swing, 2013, p. 7)

A specific aspect of migration that is attracing for our attention now is the relations among migration, borders, and global peace, in point of view of human rights. Migrants may be subjected to conflict, muliple discriminaion, violence, and exploitation, all of which often directly affect their physical and mental health. In addition, migrants may have human rights problems (Chan et al., 2013, p. 7) that are not yet protected well in all over the world. The human rights of migrants must be promoted and protected as stablished by the Vienna Declaration Programm and Action of 1993 and also the Millenium Declaration of United Nations of 2000.

The human rights of every person, specially the migrants must be promoted and protected by the authority where they live. The authorities in the borders must not obstacle the fulfilment and realizations of human rights for all the people, who pass away through them. It is obligation for the government to garantee the freedom and fundamental rights of people; those are private, civil, politic, economic, social, and culture rights. 


\section{The Promotion and Protection of Human Rights of Migrant Worker}

Mr. Ban Ki Moon, General Secretary of the United Nations on the occasion of 60th of the annyversary of the Universal Declaration of Human Rights said,

Cooperation between governments in countries of origin, transit and destination, and among non-governmental organizations, civil society and migrants themselves, is vital for ensuring that international human rights instruments are implemented and that migrants are aware of their rights and obligations. Groups with special needs, including migrant children, female labour migrants in the informal sector, traficking victims and irregular migrants, as well as refugees and asylum seekers, are particularly deserving of and entitled to effective protection.

For protecting the migrants, the United Nations on 1990 adopted International Convention on the Protection of the Rights of All Migrant Workers and Members of their Families. Fourteen years later, on July 1, 2003, this International Convention entered into force, to be an international law and must be implemented in the international level.

The Convention opens a new chapter in the history of determining the rights of migrant workers and ensuring that those rights are protected and respected. It incorporates the results of over 30 years of discussion, including United Nations human rights studies, conclusions and recommendations of meetings of experts, and debates and resolutions in the United Nations on migrant workers. (Office of the United Nations High Commissiones for Human Rights, 2005, Fact Sheet No. 24)

The fundamental rights of migrants are real and urgent to be garantee by the international law and must be respected by all nations, so this international instrument enrichs and gives new perspective.

Like all other international human rights instruments, the Convention sets standards for the laws and the judicial and administrative procedures of individual States. Governments of States that ratify or accede to the Convention undertake to apply its provisions by adopting the necessary measures. They also undertake to ensure that migrant workers whose rights have been violated may seek an effective remedy. (Office of the United Nations High Commissiones for Human Rights, 2005, Fact Sheet No. 24)

The United Nations stablishes the fundamental rights of migrants workers in the International Convention on the Protection of the Rights of All Migrant Workers and Members of their Families. In the Article 7, it stablishes that States Parties must undertake, in accordance with the international instruments concerning human and fundamental rights, to respect and to ensure to all migrant workers and members of their families within their territory or subject to their jurisdiction the rights provided for in the present Convention without distinction of any kind, such as sex, race, colour, language, religion or conviction, political or other opinion, national, ethnic, or social origin, nationality, age, economic position, property, marital status, birth, or other status. This is a real obligation for the gouverment to protect all migrant workers and members of their families. As migrant workers, they look for better life and also contribute for the countries where they live. All rights as stablish in Articles 8 until 35 are real fundamental rights that must be respected by the gouverment where the migrants workers live. They have fundamental rights as stablish in the human rights law, but also in this converntion, for exaample, in the Article 8, it stablishes that the migrant workers and members of their families shall be free to leave any State, including their State of origin. This right shall not be subject to any restrictions except those that are provided by law, are necessary to protect national security, public order (ordre public), public health or morals, or the rights and freedoms of others, and are consistent with the other rights recognized in the present part of the Convention. 
This right enriches with the other rights of migrant workers: The right to life of migrant workers and members of their families shall be protected by law (Article 9). No migrant worker or member of his or her family shall be subjected to torture or to cruel, inhuman, or degrading treatment or punishment (Article 10). No migrant worker or member of his or her family shall be held in slavery or servitude (Article 11). Migrant workers and members of their families shall have the right to freedom of thought, conscience, and religion (Article 12), the right to freedom of expression, to hold opinions without interference (Article 13), the right of privacy and property without any interference (Article 14 and 15), the right to liberty and security (Article 16), the rights of their liberty must be respected for the inherent dignity of the human person and for their cultural identity (Article 17), the right to equality with nationals of the State concerned before the courts and tribunals (Article 18), and the right to have recourse to the protection and assistance of the consular or diplomatic authorities of their State of origin or of a State representing the interests of that State whenever the rights recognized in the present Convention are impaired. In particular, in case of expulsion, the person concerned shall be informed of this right without delay and the authorities of the expelling State shall facilitate the exercise of such right (Article 23) and the right to recognition everywhere as a person before the law (Article 24).

To respect the fundamental rights of migrant workers and their families, the United Nations would like to garantee that the States parties promote and protect their rights all aspects as civilized states. This garantee is stablished on Articles 26 until 35.

Article 26

1. States Parties recognize the right of migrant workers and members of their families:

(a) To take part in meetings and activities of trade unions and of any other associations established in accordance with law, with a view to protecting their economic, social, cultural, and other interests, subject only to the rules of the organization concerned;

(b) To join freely any trade union and any such association as aforesaid, subject only to the rules of the organization concerned;

(c) To seek the aid and assistance of any trade union and of any such association as aforesaid.

2. No restrictions may be placed on the exercise of these rights other than those that are prescribed by law and which are necessary in a democratic society in the interests of national security, public order (ordre public) or the protection of the rights and freedoms of others.

Article 27

1. With respect to social security, migrant workers and members of their families shall enjoy in the State of employment the same treatment granted to nationals in so far as they fulfil the requirements provided for by the applicable legislation of that State and the applicable bilateral and multilateral treaties. The competent authorities of the State of origin and the State of employment can at any time establish the necessary arrangements to determine the modalities of application of this norm.

2. Where the applicable legislation does not allow migrant workers and members of their families a benefit, the States concerned shall examine the possibility of reimbursing interested persons the amount of contributions made by them with respect to that benefit on the basis of the treatment granted to nationals who are in similar circumstances. 
Article 28

Migrant workers and members of their families shall have the right to receive any medical care that is urgently required for the preservation of their life or the avoidance of irreparable harm to their health on the basis of equality of treatment with nationals of the State concerned. Such emergency medical care shall not be refused them by reason of any irregularity with regard to stay or employment.

\section{Article 29}

Each child of a migrant worker shall have the right to a name, to registration of birth, and to a nationality.

Article 30

Each child of a migrant worker shall have the basic right of access to education on the basis of equality of treatment with nationals of the State concerned. Access to public pre-school educational institutions or schools shall not be refused or limited by reason of the irregular situation with respect to stay or employment of either parent or by reason of the irregularity of the child's stay in the State of employment.

Article 31

1. States Parties shall ensure respect for the cultural identity of migrant workers and members of their families and shall not prevent them from maintaining their cultural links with their State of origin.

2. States Parties may take appropriate measures to assist and encourage efforts in this respect.

Article 32

Upon the termination of their stay in the State of employment, migrant workers and members of their families shall have the right to transfer their earnings and savings and, in accordance with the applicable legislation of the States concerned, their personal effects and belongings.

Article 33

1. Migrant workers and members of their families shall have the right to be informed by the State of origin, the State of employment, or the State of transit as the case may be concerning:

(a) Their rights arising out of the present Convention;

(b) The conditions of their admission, their rights and obligations under the law and practice of the State concerned, and such other matters as will enable them to comply with administrative or other formalities in that State.

2. States Parties shall take all measures they deem appropriate to disseminate the said information or to ensure that it is provided by employers, trade unions, or other appropriate bodies or institutions. As appropriate, they shall co-operate with other States concerned.

3. Such adequate information shall be provided upon request to migrant workers and members of their families, free of charge, and as far as possible, in a language they are able to understand.

Article 34

Nothing in the present part of the Convention shall have the effect of relieving migrant workers and the members of their families from either the obligation to comply with the laws and regulations of any State of transit and the State of employment or the obligation to respect the cultural identity of the inhabitants of such States.

Article 35

Nothing in the present part of the Convention shall be interpreted as implying the regularization of the 
situation of migrant workers or members of their families who are non-documented or in an irregular situation or any right to such regularization of their situation, nor shall it prejudice the measures intended to ensure sound and equitable conditions for international migration as provided in Part VI of the present Convention.

Part VI (Article 64-71) of this international convention stablishes on the Promotion of sound, equitable, humane and lawful conditions in connection with international migration of workers and members of their families

\section{Borders as Privileged Areas for Promotion and Protection of Human Rights}

Every independent country has sovranity ${ }^{1}$ and self jurisdiction to govern itself. And every country has borders. The border areas are not only as independent of territories, but as privileged areas for protecting and promoting humanity, peace, justice, and human rights. Boders have important significant as a face of the country. The government of the country, which has attention and work for humanity, without any discrimination ${ }^{2}$ in their borders really shows to the world that all the people must be realized their dignity as human person. The borders are very important and as privileged area for humanity and global peace. It is because,

The world distribution of opportunities is extremely unequal. This inequality is a key driver of human movement and thus implies that movement has a huge potential for improving human development. Yet movement is not a pure expression of choice-people often move under constraints that can be severe-while the gains they reap from moving are very unequally distributed. Our vision of development as promoting people's freedom to lead the lives they choose recognizes mobility as an essential component of that freedom. However, movement involves trade-offs for both movers and stayers, and the understanding and analysis of those trade-offs is key to formulating appropriate policies. (Human Development Report, 2009, p. 8)

The movement of the people as migrants is an expression of looking for better life and needing the protection from the authorities, specially in the borders. The function of borders is not only as line between two countries, but as areas for promoting the humanity in all aspects. The reason

For people who move, the journey almost always entails sacrifices and uncertainty. The possible costs range from the emotional cost of separation from families and friends to high monetary fees. The risks can include the physical dangers of working in dangerous occupations. In some cases, such as those of illegal border crossings, movers face a risk of death. Nevertheless, millions of people are willing to incur these costs or risks in order to improve their living standards and those of their families. A person's opportunities to lead a long and healthy life, to have access to education, health care and material goods, to enjoy political freedoms and to be protected from violence are all strongly influenced by where they live. (Human Development Report, 2009, p. 9)

The authorities of the borders should respect the humanity capable to promote the peace, manage the conflict, and protect the human rights amongts the migrants. And the urgent action today for the government is to create the culture of peace, so the global peace will be realized in all over the world.

1 The Coalition's Operation Sovereign Borders Policy, July 2013.

${ }^{2}$ Global Migration Group, International Migration and Human Rights: The Challenges and Opportunities on the Threshold of the 60 Anniversary of the Universal Declaration of Human Rights (Global Migration Group, 2008, p. 4): “In 2001, the World Conference against Racism, Racial Discrimination, Xenophobia and Related Intolerance held in Durban was a landmark in the struggle to eradicate all forms of racism. The Conference recognized that migration increased as a result of globalization, particularly from the south to the north, and stressed that policies towards migration should not be based on racism, racial discrimination, xenophobia and related intolerance. Furthermore, the Durban Conference called for a review, and where necessary, revision of any immigration policy inconsistent with internationa human rights instruments, with a focus on the elimination of all discriminatory polici es and practices against migrants”. 
The migrants give also contributions for the countries they live, the origin country, and also the world. Now, many discussions on what contributions and significance of migration to sustainable development. The migrants are not only the movements of the people to the other countries, but also the movements for better life. In the global era, the world must be considered as a society more peaceful and capable to develop all aspects for the people. In the RIO 2012 Issues Briefs written as follow:

Human mobility at international and internal scales is at its highest levels in recorded history. Although the share of international migrants in the world's population has remained at approximately 3 percent for more than 20 years, their absolute numbers have increased significantly: in 1990, approximately 156 million people lived outside their country of birth, but today this has increased to approximately 215 million. At the same time, today approximately 740 million internal migrants are estimated to have moved away from their places of birth within the borders of their own countries. The headline figure is thus that one person in seven in the world is in a migratory state in some form: migration has accelerated to become a global mega-trend of the 21st century. Moreover, migrants are more culturally and ethnically diverse than ever before, and more women are migrating today either on their own or as heads of households. In recent years, international and internal migration has increasingly been recognized as a positive force for development, as migrants transfer knowledge and skills to both receiving and origin locations, channel investments and remittances, and foster economic linkages and business opportunities between coutries and regions. Carefully managed migration can promote economic growth and innovation in destination locations, and poverty reduction in origin locations. At the same time, while migration can to a certain extent offset labour surpluses in sending countries, receiving countries are taking on associated multiple challenges, including managing labour markets. Harnessing the opportunities that migration provides while addressing its challenges will require countries to create policy and legal frameworks that recognize the patterns and drivers of level, migration is stimulated by the globalization of trade, migration, as well as the characteristics of migrants themselves. (2012, p. 1)

We hope the migrants give contributions with action to the world more peaceful and the government and people in countries where they live more respect to their human rights, and the global peace must be promoted to all over the world. And we must participate actively for this promotion and collaborate with whom have good will for it. What Mr. Koffi Annan, the former of United general Secretary, said on his acceptance speech upon receiving the 2001 Nobel Peace Prize is:

...we must start from the understanding that peace belongs not only to states or peoples, but to each and every member of those communities. The sovereignty of States must no longer be used as a shield for gross violations of human rights. Peace must be made real and tangible in the daily existence of every individual in need. Peace must be sought, above all, because it is the condition for every member of the human family to live a life of dignity and security.

The obligation of the gouverment to fulfil all human rights for migrant workers and their families must be realized, speacially in the borders areas.

\section{Conclusion}

Borders of the country should be privileged areas for promotion and protection of human rights for the migrant workers and their families. For this reason, all the countries, which have the borders, must colaborate one and another to respect and fulfil the fundamental rights, specially which has decreed by the United Nations. The borders must be face of the country for promoting and protecting the huaman rights today. 


\section{BORDERS AS PRIVILEGED AREAS FOR PROMOTION AND PROTECTION OF HUMAN RIGHTS}

\section{References}

Annan, K. (2001, Decembre 10). Nobel lecture, Oslo.

Baudet, T. H. P. (2012). The significance of borders: Why representative goverment and the rule of law requires nation states. Leiden: Leiden University.

Chan, M., Pillay, N., \& Swing, W. L. (2013). International migration: Health and human rights. World Health Organizaion, United Naions High Commissioner for Human Rights, International Organizaion for Migration, Geneva.

Global Migration Group. (2008). International migration and human rights: The challenges and opportunities on the threshold of the 60 Anniversary of the Universal Declaration of Human Rights.

Human Development Report. (2009). Overcoming barriers: Human mobility and development. New York, N.Y.: The United Nations Development Programme.

Office of the United Nations High Commissiones for Human Rights. (2005). The International Convention on Migrant Workers and Its Committee, Fact Sheet No. 24. New York and Geneva.

The UNCSO Secretariat. (2012, June). Migration and sustainable development. RIO 2012 Issue Brief No. 15. 